\title{
Muscle Denervation Increases the Levels of Two mRNAs Coding for the Acetylcholine Receptor $\alpha$-Subunit ${ }^{1}$
}

\author{
DANIEL GOLDMAN, ${ }^{2}$ JIM BOULTER, STEVE HEINEMANN, AND JIM PATRICK
}

Molecular Neurobiology Laboratory, The Salk Institute, P. O. Box 85800, San Diego, California 92138

\begin{abstract}
The mRNA coding for the $\alpha$-subunit of the acetylcholine receptor was studied in mouse leg and rat diaphragm muscle. We find that denervation of rat diaphragm results in a 7-fold increase in mRNA coding for the $\alpha$-subunit, whereas denervation of mouse leg muscle results in approximately a 50fold increase in $\alpha$-subunit-specific mRNA. The relationship of the mRNAs purified from innervated and denervated muscle was investigated by SI nuclease mapping. Two mRNA species were found in both innervated and denervated muscle which differ in their $3^{\prime}$-untranslated region. The levels of both these mRNA species increase upon denervation of mouse leg muscle.
\end{abstract}

Acetylcholine receptor is found localized at the neuromuscular junction of adult mammalian skeletal muscle (Miledi, 1960b). Denervation of muscle results in a large increase in the synthesis of acetylcholine receptor. This newly synthesized receptor is no longer localized to junctional regions of the muscle fiber and is mostly incorporated into extrajunctional regions (Axelsson and Thesleff, 1959; Miledi, 1960a). Furthermore, receptor molecules found at junctional regions differ both biochemically and biophysically from those found in extrajunctional regions (Brockes and Hall, 1975; Neher and Sakmann, 1976). The mechanism responsible for the regulation of receptor synthesis and the reason for the different properties of junctional and extrajunctional receptor are not known. It is clear that the level of electrical activity in muscle plays a role in regulating receptor incorporation since direct stimulation of muscle can prevent the formation of extrajunctional receptors (Lømo and Westgard, 1975; Hall and Reiness, 1977). Furthermore, it has recently been shown that muscle denervation results in an increase in levels of acetylcholine receptor-specific mRNA (Merlie et al., 1984). The difference between junctional and extrajunctional receptor may be due to different gene products or post-transcriptional processing of a single gene product. In order to investigate the relationship of junctional and extrajunctional mRNA we performed SI nuclease protection experiments on mRNA, coding for the acetylcholine receptor, isolated from innervated and denervated muscle. The results reported here show that denervation results in an increase in two

Received December 11, 1984; Revised January 29, 1985;

Accepted January 29, 1985

${ }^{1}$ We thank Dr. Inder Verma for providing us with the $\mathrm{c}$-Ha-ras 1 recombinant DNA plasmid, Dr. Walter Luyten for helpıng with dissections, and Karen Evans for DNA sequence data. We gratefully acknowledge support for this work from the Amoco Foundation, the Keck Foundation, National Institutes of Health research grants to S. H. and J. P., and Muscular Dystrophy Association research grants to $S$. $H$. and J.P.

${ }^{2}$ To whom correspondence should be addressed. species of mRNA coding for the acetylcholine receptor $\alpha$-subunit that differ in their $3^{\prime}$-untranslated regions.

\section{Materials and Methods}

Muscle denervation. Experiments were performed on male SpragueDawley rats and BALB/C mice. The phrenic nerve innervating the left hemidiaphragm was sectioned while rats were under ether anesthesia. The right hemidiaphragm served as an innervated control. Mice were anesthetized with methoxyflurane (Metatane), and the sciatic nerve was cut in the thigh. The right hindlimb served as an innervated control. Five days after denervation right and left hemidiaphragms (rat) or right and left lower hindlimb plantar extensor muscles (mice) were removed.

RNA purification. RNA was isolated by a method based on that of Chirgwin et al. (1979); 2 to $4 \mathrm{gm}$ of tissue were pulverized in liquid nitrogen and homogenized in $25 \mathrm{ml}$ of buffered $5 \mathrm{M}$ guanidine thiocyanate (Chirgwin et al., 1979). A Polytron (Brinkmann Instruments) was used to achieve rapid homogenization. The homogenates were centrifuged for $10 \mathrm{~min}$ at 2,500 $\mathrm{rpm}$ in an IEC HN-SII centrifuge at room temperature. The supernatant was passed through a series of syringe needles, 18,22 , and 25 gauge, respectively, and then centrifuged at $10,000 \mathrm{rpm}$ for $20 \mathrm{~min}$ in a Sorvall SS34 rotor at $10^{\circ} \mathrm{C}$. The supernatant was layered over a $3 \cdot \mathrm{ml}$ cushion of $5.7 \mathrm{M} \mathrm{CsCl}, 50$ mM EDTA, pH 7.8, and centrifuged for 15 to $17 \mathrm{hr}$ at $35,000 \mathrm{rpm}, 20^{\circ} \mathrm{C}$ in a Beckman SW41 rotor. The solution above the $\mathrm{CsCl}$ cushion was removed and the sides of the tube were washed with $2 \mathrm{ml}$ of $5 \mathrm{~m}$ guanidine thiocyanate. This was repeated a few times, each time removing some of the $\mathrm{CsCl}$ until all $\mathrm{CsCl}$ was removed. The top two-thirds of the tube was cut off and discarded. The RNA pellet was resuspended in $1 \mathrm{ml}$ of $\mathrm{H}_{2} \mathrm{O}$. Buffered guanidine hydrochloride $(6.5 \mathrm{ml})$ (Chirgwin et al., 1979) was then added and the solution was mixed until the RNA pellet dissolved. The solution was acidified by addition of $0.025 \mathrm{vol}$ of $1 \mathrm{M}$ acetic acid. RNA was precipitated by addition of 0.5 vol of absolute ethanol, mixing thoroughly, and placing the solution at $-70^{\circ} \mathrm{C}$ for a minimum of $1 \mathrm{hr}$. RNA was sedimented by centrifugation for $15 \mathrm{~min}$ at $10,000 \mathrm{rpm}$ in a Sorvall SS34 rotor at $4^{\circ} \mathrm{C}$. Supernatant was removed and pellets were washed with absolute ethanol. Pellets were dried briefly under vacuum and resuspended in $2 \mathrm{ml}$ of $\mathrm{H}_{2} \mathrm{O}$, and the $\mathrm{pH}$ was adjusted to 7 to 8 with $1 \mathrm{~N} \mathrm{NaOH}$. The solution was then spun at 15,000 $\mathrm{rpm}$ for $15 \mathrm{~min}$ in the Sorvall SS34 rotor at $4^{\circ} \mathrm{C}$. The RNA was precipitated from the supernatant by addition of 0.1 vol of $2 \mathrm{M}$ potassium acetate, $\mathrm{pH}$ 5.2 , and $2.5 \mathrm{vol}$ of absolute ethanol and placing at $-70^{\circ} \mathrm{C}$ for a minimum of $2 \mathrm{hr}$. Poly $(A)^{+}$RNA was selected by chromatography over an oligo (dT)cellulose column (Aviv and Leder, 1972). The material not adhering to the column is referred to as poly(A)- RNA.

Denaturing agarose gel analysis of RNA and Northern blot hybridization. RNA was denatured in formaldehyde at $65^{\circ} \mathrm{C}$ and electrophoresed in $2.2 \mathrm{M}$ formaldehyde, $1.1 \%$ agarose gels (Potter et al., 1981). The RNA was then transferred to nitrocellulose membrane (Thomas, 1980). Prehybridization and hybridization were performed according to the method of Thomas (1980), except that prehybridization was for 1 to $5 \mathrm{hr}$ and the solution contained dextran sulfate $(10 \% \mathrm{w} / \mathrm{v})$. The hybridization probe was a recombinant DNA plasmid containing CDNA coding for the $\alpha$-subunit of the acetylcholine receptor (Boulter et al., 1985). The probe was labeled with ${ }^{32} \mathrm{P}$ by nicktranslation (Rigby et al., 1977), to a specific activity of 2 to $8 \times 10^{8} \mathrm{cpm} / \mu \mathrm{g}$. After hybridization the nitrocellulose membrane was washed in 2X SSPE (1X SSPE is $180 \mathrm{~mm} \mathrm{NaCl}, 9 \mathrm{~mm} \mathrm{Na} 2 \mathrm{HPO}_{4}, 0.9 \mathrm{~mm} \mathrm{NaH}_{2} \mathrm{PO}_{4}, 1 \mathrm{~mm}$ EDTA, pH 7.4), $0.05 \%$ sodium dodecyl sulfate (SDS) at room temperature followed by $0.1 \mathrm{XSSPE}, 0.05 \%$ SDS at $65^{\circ} \mathrm{C}$ and was exposed to $\mathrm{x}$-ray film with intensifying screen for $3 \mathrm{hr}$ at $-70^{\circ} \mathrm{C}$. 


\author{
RAT \\ DIAPHRAGM \\ MUSCLE
}

\section{MOUSE LEG MUSCLE}

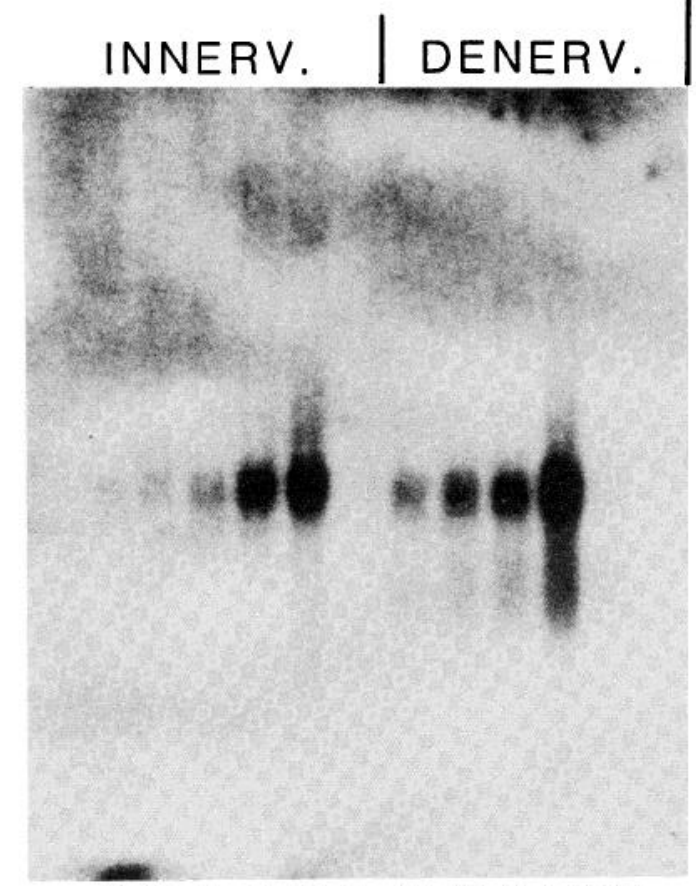

$1234567891011 \quad 1213$

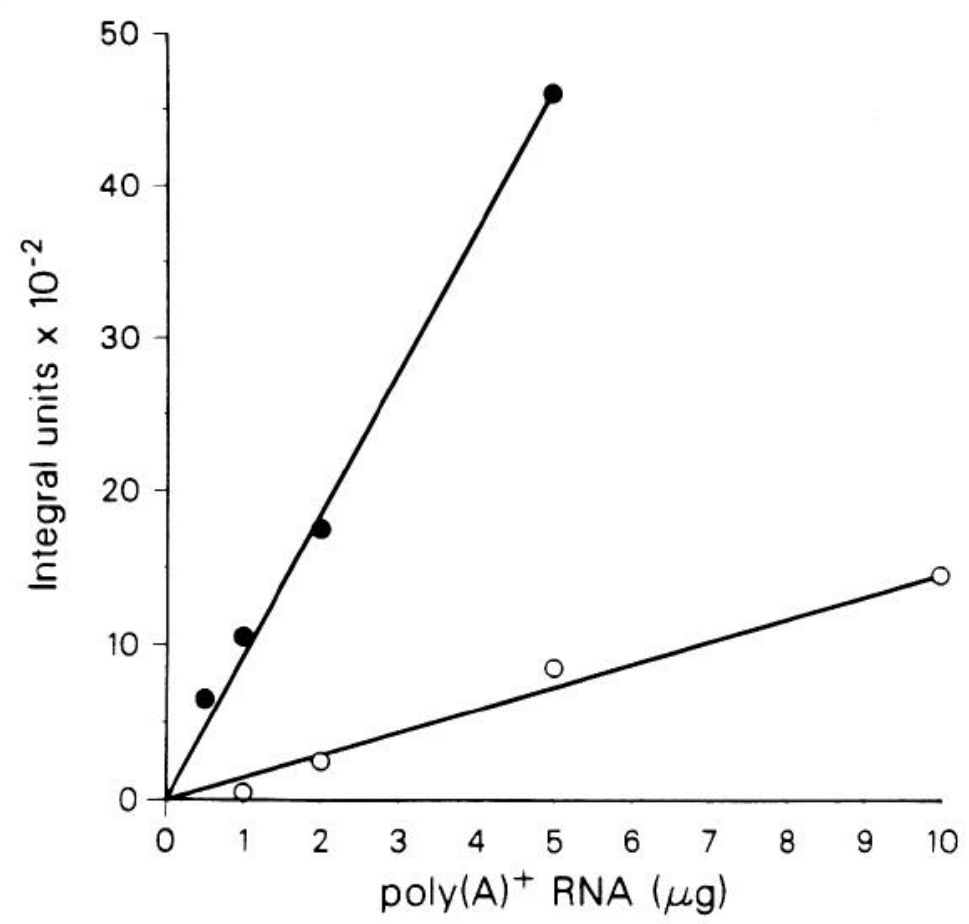

\section{$18 \mathrm{~S}$ rRNA}

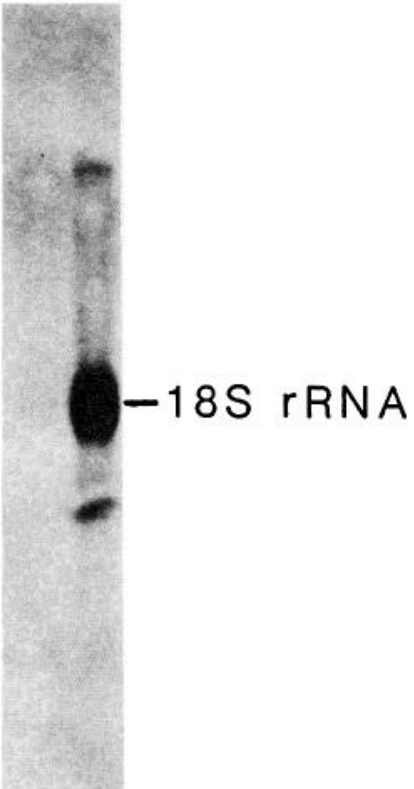

Fig. 1. Effect of denervation on levels of mRNA coding for the $\alpha$-subunit of the acetylcholine receptor. A, Lanes 1 to 6 are RNA isolated from innervated rat hemidiaphragms. Lanes 1 to 5 contain $0.5,1$, 2,5 , and $10 \mu \mathrm{g}$ of poly $(\mathrm{A})^{+} \mathrm{RNA}$, respectively. Lane 6 contains $10 \mu \mathrm{g}$ of poly(A) ${ }^{-}$ RNA. Lanes 7 to 11 are RNA isolated from denervated rat hemidiaphragms. Lanes 7 to 10 contain $0.5,1,2$, and $5 \mu \mathrm{g}$ of poly $(\mathrm{A})^{+}$RNA, respectively. Lane 11 contains $5 \mu \mathrm{g}$ of poly(A) RNA. Lanes 12 and 13 contain 4.6 and $3.3 \mu \mathrm{g}$ of poly(A) ${ }^{+}$RNA isolated from innervated and denervated mouse leg muscle, respectively. $B$, Quantitation of relative levels of rat diaphragm poly $(\mathrm{A})^{+} \mathrm{RNA}$ coding for the $\alpha$-subunit of the acetylcholine receptor. The autoradiogram in $A$ was scanned with a densitometer and the integral of the peaks was determined. Plotted is the integral of the scan versus micrograms of poly $(A)^{+}$RNA applied to the gel. RNA was isolated from 5-day denervated hemidiaphragms (๑) and innervated hemidiaphragms $(\mathrm{O})$. 
Slot blot analysis of RNA. Various amounts of poly $(A)^{+}$RNA were mixed with $10 \mu \mathrm{g}$ of tRNA in a final volume of $50 \mu \mathrm{l}$. To this RNA was added $30 \mu \mathrm{l}$ of $20 \mathrm{XSSPE}$ and $20 \mu \mathrm{l}$ of $37 \%$ formaldehyde. Samples were heated at $65^{\circ} \mathrm{C}$ for $15 \mathrm{~min}$ and applied to nitrocellulose using a Schleicher and Schuell Minifold II slot blotting apparatus. Samples were washed through wells with $0.5 \mathrm{ml}$ of $20 \mathrm{XSSC}$. The nitrocellulose membrane was baked at $80^{\circ} \mathrm{C}$ under vacuum and prehybridized, hybridized, and washed as described for Northern blot hybridization. The cDNA coding for the $\alpha$-subunit and the c-Ha-ras 1 probes were labeled by nick translation to a specific activity of $5.4 \times 10^{8}$ $\mathrm{cpm} / \mu \mathrm{g}$ and $4.6 \times 10^{8} \mathrm{cpm} / \mu \mathrm{g}$, respectively. The nitrocellulose membranes were exposed to $x$-ray film for $4 \mathrm{hr}$.

SI nuclease analysis. Denervated or innervated mouse leg muscle mRNA was mixed with approximately $100 \mathrm{ng}$ of complementary $\alpha$-subunit CDNA corresponding to the $5^{\prime} 450-, 3^{\prime} 1270$-, or $3^{\prime} 546$-nucleotide-long region which was subcloned into the single-stranded phage M13 (see Fig. 3). These samples were ethanol precipitated and resuspended in $20 \mu$ l of hybridization buffer (Maniatis et al., 1982). Samples were heated to $85^{\circ} \mathrm{C}$ for $10 \mathrm{~min}$ and incubated at $42^{\circ} \mathrm{C}$ for $3 \mathrm{hr}$. Samples were then diluted with $0.3 \mathrm{ml}$ of SI nuclease buffer (Maniatis et al., 1982), containing 240 units of nuclease $\mathrm{SI}$ and $5 \%$ glycerol, vortexed, and placed at $37^{\circ} \mathrm{C}$ for $30 \mathrm{~min}$. Reactions were terminated by addition of ammonium acetate to $0.67 \mathrm{M}$, EDTA to $8.3 \mathrm{~mm}$, and the RNA:DNA hybrids were ethanol precipitated. Samples were washed twice with $70 \%$ ethanol, resuspended in $20 \mu \mathrm{l}$ of deionized formamide, and heated to $70^{\circ} \mathrm{C}$ for $15 \mathrm{~min}$. Sl-resistant hybrids were analyzed by electrophoresis through a $3 \%$ polyacrylamide- $8 \mathrm{M}$ urea gel and electrophoretically transferred to Gene Screen Plus according to the manufacturer's directions. The blot was prehybridized and hybridized as described in Northern blot hybridization except that the SDS concentration was increased to $1 \%(\mathrm{w} / \mathrm{v})$ and formamide was omitted.

Quantitation of RNA. RNA was quantitated by measuring the absorbance of an aqueous solution at $260 \mathrm{~nm}$. An absorbance of 1 corresponds to approximately $40 \mu \mathrm{g} / \mathrm{ml}$ of single-stranded RNA.

\section{Results}

Muscle denervation increases the levels of mRNA coding for acetylcholine receptor $\alpha$-subunit. RNA was size fractionated on denaturing formaldehyde agarose gels (Potter et al., 1981) and transferred to nitrocellulose membranes (Thomas, 1980). mRNA corresponding to the $\alpha$-subunit of the acetylcholine receptor was detected by hybridization (Thomas, 1980) to nick-translated cDNA containing sequences coding for the $\alpha$-subunit of mouse acetylcholine receptor (Boulter et al., 1985). This cDNA clone was isolated from a cDNA library prepared using poly $(\mathrm{A})^{+}$-selected RNA obtained from the non-fusing muscle cell line $\mathrm{BC}_{3} \mathrm{H}-\mathrm{I}$ (Schubert et al., 1974; Patrick et al., 1977; Boulter et al., 1985). This clone contains sequences that code for a protein which exhibits greater than $90 \%$ amino acid sequence homology to the human $\alpha$-subunit (Noda et al., 1983) and codes for the entire mature $\alpha$-subunit (Boulter et al., 1985).

Nick-translated $\alpha$-subunit cDNA is observed to hybridize to a broad band of poly $(\mathrm{A})^{+}$-selected RNA from both innervated and denervated rat diaphragm and mouse leg muscle (Fig. 1). Based on the mobility of $18 \mathrm{~S}$ rRNA, the mRNA coding for the $\alpha$-subunit is approximately 2 kilobases $(\mathrm{kb})$. This is consistent with the results of Merlie et al. (1984). A significant increase in the abundance of $\alpha$ subunit-specific mRNA is observed in denervated muscle (Fig. 1A).
Quantitation of the increase in mRNA, from rat diaphragm, coding for the $\alpha$-subunit was performed by densitometer scanning of films (as in Fig. 1A) and plotting the integral of the scan versus the amount of mRNA applied to the gel (Fig. 1B). The integral is proportional to the amount of mRNA applied to the gel. The increase in $\alpha$-subunitspecific mRNA was calculated from the slope of these lines. From this analysis we calculate that denervation results in a 7-fold increase in the amount of $\alpha$-subunit-specific mRNA. These data, taken in conjunction with previous experiments using inhibitors of RNA synthesis (Fambrough, 1970; Chang and Tung, 1974), suggest that the denervation-induced increase in mRNA levels coding for acetylcholine receptor $\alpha$-subunit is the result of increased transcription of the $\alpha$-subunit gene. Run-off transcription experiments with nuclei isolated from innervated and denervated muscle will be necessary to confirm this conclusion.

Is there a general effect of muscle denervation on mRNA levels? Denervation is known to change a number of other muscle properties in addition to the synthesis of acetylcholine receptor (Beresford et al., 1976; Maskrey et al., 1977). In order to examine the possibility that denervation nonspecifically increases mRNA synthesis, we performed two types of analyses. First we measured the amount of poly $(\mathrm{A})^{+} \mathrm{RNA}$ that was extractable from innervated and denervated diaphragms. We recovered $123 \mu \mathrm{g}$ of $\mathrm{poly}(\mathrm{A})^{+} \mathrm{RNA} / \mathrm{gm}$ of innervated diaphragm and $118 \mu \mathrm{g}$ of poly $(\mathrm{A})^{+} \mathrm{RNA} / \mathrm{gm}$ of denervated diaphragm. Thus, there are no significant differences in the amounts of $\operatorname{poly}(A)^{+}$RNA that can be isolated from these tissues, at least 5 days after denervation. In the second experiment we measured the amount of mRNA coding for a gene whose expression is not expected to be regulated by denervation. We chose the c-Ha-ras 1 proto-oncogene (Chang et al., 1982; Parada et al., 1982), which is expressed at relatively low levels in nontransformed tissues (Chang et al., 1982; Muller et al., 1982; Parada et al., 1982) and is not a muscle-specific protein. Poly(A) ${ }^{+}$-selected RNA was bound to nitrocellulose filters and hybridized with either a nick-translated plasmid containing the genomic 2.9-kb Sac 1 fragment of c-Ha-ras 1 (Chang et al., 1982) or the mouse $\alpha$-subunit cDNA (Fig. 2). The results in Figure 2 show that the c-Ha-ras 1 gene is expressed at low levels in muscle and its level is not influenced by denervation, whereas the level of acetylcholine receptor $\alpha$-subunit-specific mRNA increases after denervation. These two results rule out the possibility that the effect on mRNA coding for the acetylcholine receptor is due to a general increase in mRNA levels following denervation.

SI nuclease analysis. Is there only a single species of mRNA coding for the $\alpha$-subunit of the acetylcholine receptor? Agarose gels indicated that there is a broad band of RNA that hybridized to the $\alpha$-subunit cDNA, which suggests that more than one species of RNA is hybridizing to the cDNA probe. To determine whether more than one species of mRNA is contributing to this hybridization signal we used SI nuclease digestion (Maniatis et al., 1982) of heteroduplexes formed between the mRNA and regions of the cDNA clone coding for the mouse $\alpha$-subunit. The cDNA clone contains a Pst 1 site about $450 \mathrm{bp}$ from the $5^{\prime}$ end (including 26 bases coding for the leader peptide) and two RSA 1 sites generating a $3^{\prime}$ fragment
Figure 2. Slot blot determination of RNA coding for the acetylcholine receptor versus the proto-oncogene c-Ha-ras1. Poly $(A)^{+}$RNA was isolated from 5-day denervated $(A$ and $D)$ or control innervated $(B$ and $E)$ rat hemidiaphragms. $C$ and $F$ correspond to tRNA used as carrier in the other samples. Various amounts of poly $(A)^{+}$RNA were applied to the nitrocellulose membrane and probed with ${ }^{32} \mathrm{P}$ labeled cDNA coding for the $\alpha$-subunit of the acetylcholine receptor $(A$ to $C)$ or the c-Ha-ras 12.9 -kb probe $(D$ to $F$ ). Numbers 1 to 4 correspond to $0.25,0.5,1$, and 3 $\mu \mathrm{g}$ of poly $(\mathrm{A})^{+} \mathrm{RNA}$, except $C$ and $F$ which each contain $10 \mu \mathrm{g}$ of tRNA.
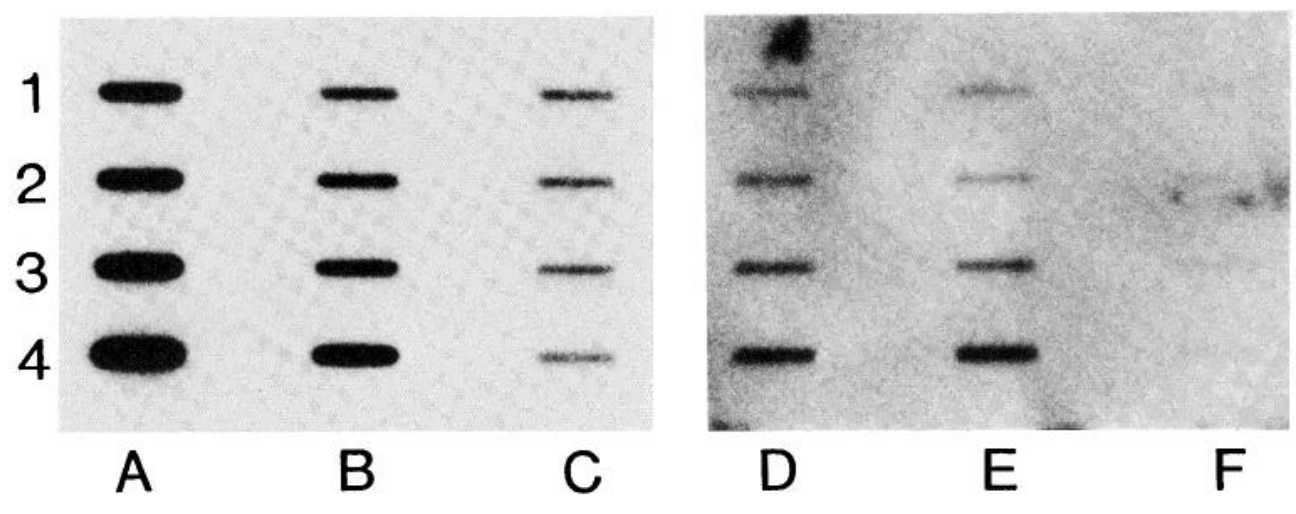
A
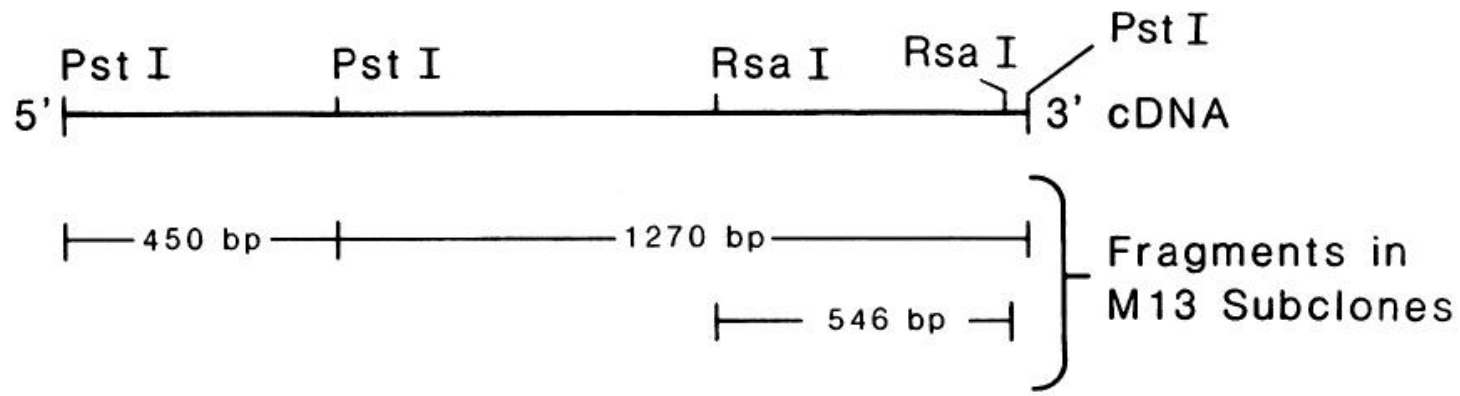

B

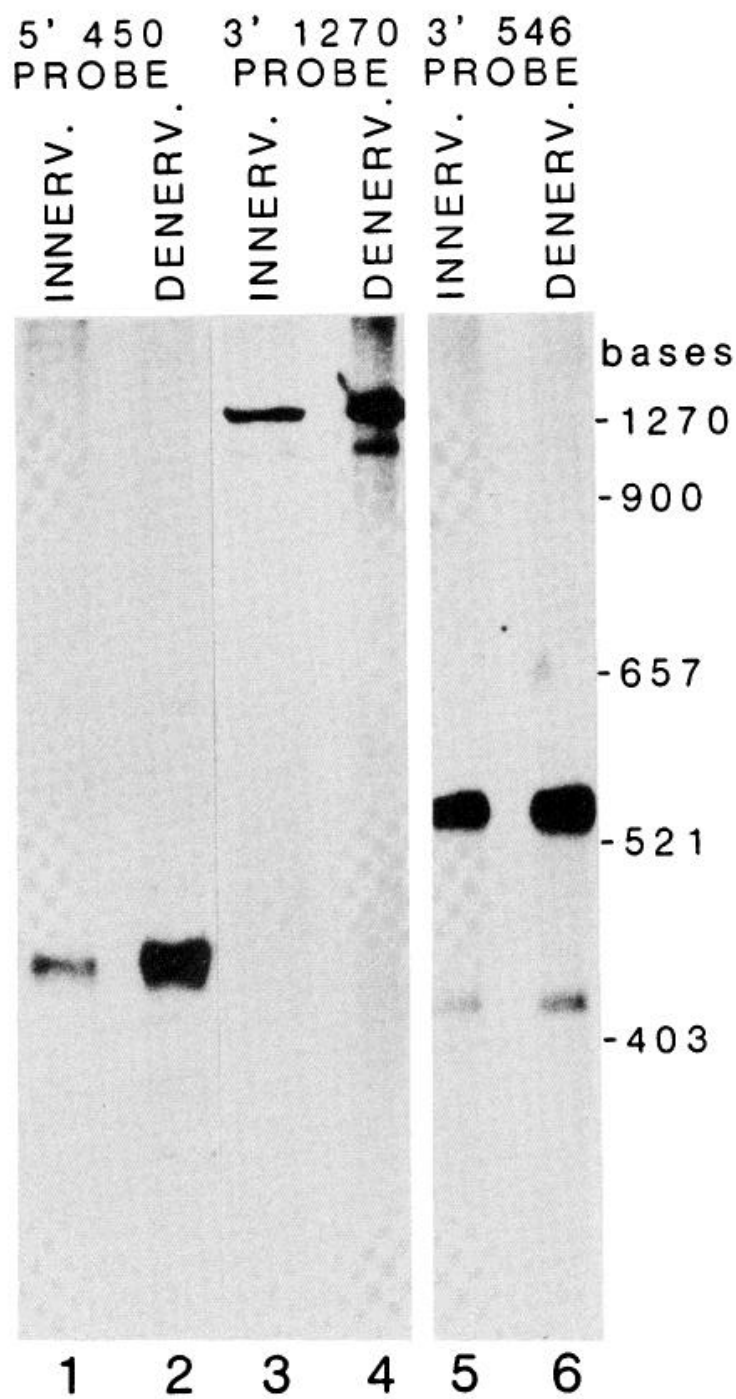

Figure 3. SI nuclease analysis of mouse mRNAs. A, Fragments of cDNA subcloned into M13 for hybridization with mRNA. $B$, Gel profile of SI nucleaseprotected fragments generated by SI nuclease digestion of heteroduplexes formed between innervated or denervated mouse leg muscle mRNA and the various $\mathrm{M} 13$ subclones in $A$. Lanes 1,3 , and 5 represent SI nuclease-resistant fragments generated by hybridizing innervated mouse leg muscle mRNA (40 $\mu \mathrm{g}$ ) with the $5^{\prime}$ 450-, 3' 1270-, and 3' 546-nucleotide-long subclones, respectively. Lanes 2, 4, and 6 represent SI nuclease-resistant fragments generated by hybridizing denervated mouse mRNA ( $1 \mu \mathrm{g})$ with the $5^{\prime} 450-3^{\prime} 1270-$, and $3^{\prime}$ 546-nucleotide-long subclones, respectively.

of about $546 \mathrm{bp}$ (lacking $7 \mathrm{bp}$ at the extreme $3^{\prime}$ end). Three M13 subclones were prepared (Fig. $3 A$ ), one containing the mRNA complement of the 450 bases at the $5^{\prime}$ end of the clone, a second containing the mRNA complement of the remaining 1270 bases extending to the $3^{\prime}$ end of the clone, and a third containing the mRNA complement of the 546 bases at the extreme $3^{\prime}$ end of the clone. mRNA, obtained from innervated or denervated mouse leg muscle, was separately hybridized to single-strand DNA isolated from these M13 subclones. The samples were digested with SI nuclease, electrophoresed through a $3 \%$ polyacrylamide- $8 \mathrm{M}$ urea gel, and electroblotted to Gene Screen Plus. The sequences surviving $\mathrm{SI}$ nuclease digestion were visualized by hybridization with a nick-translated probe prepared from the entire cDNA clone (Fig. 3B).

When this analysis was performed with mRNA, obtained from innervated or denervated mouse leg muscle, and the $5^{\prime} 450$ nucleotide-long subclone, a single fragment of 450 bases was 


\title{
1540

\author{
$1620 \quad 1640 \quad 1660 \quad 1680$

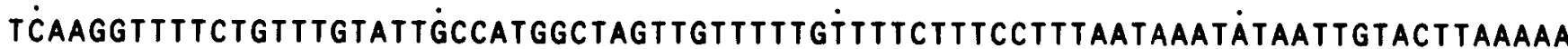

Figure 4. DNA sequence of the $3^{\prime}$ end of the $\alpha$-subunit cDNA clone. Putative polyadenylation signals are underlined.

protected (Fig. 3). Since our cDNA clone is missing sequences coding for part of the leader and $5^{\prime}$-untranslated region, there may exist heterogeneity in the MRNA at the extreme $5^{\prime}$ end that escaped our detection. Hybridization of mRNA with the 1270-nucleotide-long $3^{\prime}$ subclone, followed by digestion with SI nuclease, generates two protected fragments of approximately 1270 and 1100 bases. These fragments must result from protection of the 1270-nucleotide-long $3^{\prime}$ subclone by two different mRNA species. Using the $3^{\prime} 546$ nucleotide-long subclone we have localized the size difference in the mRNAs to the extreme $3^{\prime}$ end of the message. These gels indicate that the two messages differ by about 130 bases.

DNA sequence analysis. DNA sequence analysis indicates that there are three putative polyadenylation signals (Proudfoot and Brownlee, 1976) at the $3^{\prime}$ end of the cDNA clone (Fig. 4) (Boulter et al., 1985). The first is separated from the other two by 124 and 128 bp. This is in good agreement with the SI nuclease analysis (Fig. $3 B$ ). Since the more abundant message is the longer one, it is the second and/or third polyadenylation signal that is used preferentially.

\section{Discussion}

The finding that muscle denervation increases the levels of acetylcholine receptor-specific mRNA is consistent with the idea that electrical activity influences acetylcholine receptor gene expression. The finding of only a 7 fold incrcase of $\alpha$-subunit-specific mRNA upon denervation of rat diaphragm compared to a 50- to 100-fold increase in this mRNA upon denervation of the mouse leg muscle is surprising. The increase in the number of extrajunctional receptors upon denervation (anywhere from 5- to 30-fold) is accompanied by an increased turnover rate of the receptor protein (reviewed in Edwards, 1979). Extrajunctional receptor in denervated muscle has a metabolic half-life of about $17 \mathrm{hr}$, whereas junctional receptor in innervated muscle has a half-life of about 10 days. This suggests an increase in synthetic rate of at least 70 -fold. It appears that for rat diaphragm the denervation-induced increase in the level of mRNA coding for the $\alpha$-subunit is insufficient to account for the elevation of receptor number and turnover. Thus, in addition to transcription and mRNA stability, other post-transcriptional processes may be important in determining the amount of functional receptor in denervated rat diaphragm muscle. In fact, there has been the suggestion that post-translational controls may be involved in determining the number of functional receptor molecules in the muscle cell line $\mathrm{BC}_{3} \mathrm{H}-\mathrm{I}$ (Olson et al., 1984). However, recently there has been a report that denervation of mouse skeletal muscle results in a 100fold increase in $\alpha$-subunit-specific mRNA (Merlie et al., 1984). These investigators conclude that this increase upon denervation is sufficient to account for acetylcholine receptor levels. We find similar resulls with the mouse leg muscle (Fig. $1 A$ ). The reason for a 7 -fold difference for rat diaphragm muscle and the 100-fold difference observed in mouse leg muscle upon denervation is not clear. It may reflect differences between the muscles studied. We are currently investigating the influence of denervation on different muscle types.

We performed SI nuclease analysis ir urder to determine the relationship of junctional and extrajunctional $\alpha$-subunit-specific mRNAs. These experiments did not detect any difference between the mRNAs synthesized in innervated and denervated muscle. Only the abundance of the mRNAs changes after denervation. This is consistent with the idea that there is only one gene coding for the junctional and extrajunctional $\alpha$-subunit protein (Klarsfeld et al., 1984). Thus, it is likely that any biochemical differences that exist between $\alpha$-subunits obtained from junctional and extrajunctional regions of the muscle fiber arise from post-translational events (Hall et al., 1983).

The finding of two mRNA species differing in their polyadenylation sites is intriguing. Both messages increase upon denervation of muscle tissue. The significance of producing two messages differing in their $3^{r}$-untranslated region is unclear. Perhaps differences in the $3^{\prime}$-untranslated region confer differential stability, translatability, or compartmentalization on the two mKNA species. There are a number of examples where a single-copy gene produces multiple RNAs by differential use of multiple polyadenylation sites (Zehner and Paterson, 1983; Legace et al., 1983; Parnes et al., 1983). However, there is no clear functional difference assigned to the various transcripts that differ in their $3^{\prime}$-untranslated region.

Finally, it should be kept in mind that the acetylcholine receptor is a multi-subunit protein and that regulation of functional receptor levels may be a result of differential regulation of individual subunits.

\section{References}

Aviv, H., and P. Leder (1972) Purification of biologically active globin messenger RNA by chromatography over oligothymidylic acid-cellulose. Proc. Natl. Acad. Sci. U. S. A. 69: 1408-1412.

Axelsson, J., and S. Thesleff (1959) A study of supersensitivity in denervated mammalian skeletal muscle. J. Physiol. (Lond.) 147: 178-193.

Beresford, B. J., M. P. Rathbone, and D. M. Logan (1976) Evidence for a selective stimulation of myosin synthesis following muscle denervation. Exp. Neurol. 52: 177-188.

Boulter, J., W. Luyten, K. Evans, P. Mason, M. Ballivet, D. Goldman, S. Stengelin, G. Martin, S. Heinemann, and J. Patrick (1985) Isolation of a clone coding for the $\alpha$-subunit of a mouse acetylcholine receptor. J. Neurosci. 5: 2545-2552

Brockes, J. P., and Z. W. Hall (1975) Acetylcholine receptors in normal and denervated rat diaphragm muscle. II. Comparison of junctional and extrajunctional receptors. Biochemistry 14: 2100-2106.

Chang, C. C., and L. H. Tung (1974) Inhibition by actinomycin D of the generation of acetylcholine receptors induced by denervation in skeletal muscle. Eur. J. Pharmacol. 26: 386-388

Chang, F. H., M. F. Furth, E. M. Scolnick, and D. R. Lowry (1982) Tumorigenic transformation of mammalian cells induced by a normal human gene homologous to the oncogene of Harvey murine sarcoma virus. Nature 297: 479-483.

Chirgwin, J. M., A. E. Przybyla, R. J. MacDonald, and W. J. Rutter (1979) Isolation of biologically active ribonucleic acid from sources enriched in ribonuclease. Biochemistry 18: 5294-5299.

Edwards, C. (1979) The effects of innervation on the properties of acetylcholine receptors in muscle. Neuroscience 4: 565-584.

Fambrough, D. M. (19/0) Acetylcholine sensitivity of muscle fiber membranes: Mechanism of regulation by motorneurons. Science 168: 372373.

Hall, Z. W., and C. G. Reiness (1977) Electrical stimulation of denervated muscles reduces incorporation of methionine into the ACh receptor. Nature 231: 296-301.

Hall, Z. W., M. -P. Roisin, Y. Gu, and P. D. Gorin (1983) A developmental change in the immunological properties of acetylcholine receptors at the rat neuromuscular junction. Cold Spring Harbor Symp. Quant. Biol. 48: 101-108

Klarsfeld, A., A. Devillers-Thiery, J. Giraudat, and J. -P. Changeux (1984) A 
single gene codes for the nicotinic acetylcholine receptor $\alpha$-subunit in Torpedo marmorata: Structural and developmental implications. EMBO J. 3: 35-41.

Legace, L., T. Chandra, S. L. C. Woo, and A. R. Means (1983) Identification of multiple species of calmodulin messenger RNA using a full length complementary DNA. J. Biol. Chem. 258: 1684-1688.

Lømo, T., and R. H. Westgard (1975) Further studies on the control of ACh sensitivity by muscle activity in the rat. J. Physiol. (Lond.) 252: 603-626.

Maniatis, T., E. F. Fritsch, and J. Sambrook (1982) Molecular Cloning: A Laboratory Manual, Cold Spring Harbor Laboratory, Cold Spring Harbor, NY.

Maskrcy, P., M. G. Pluskal, J. B. Harris, and R. J. T. Pennington (1977) Studies on increased acid hydrolase activities in denervated muscle. $\mathrm{J}$. Neurochem. 28: 403-409.

Merlie, J. P., K. E. Isenberg, S. D. Russell, and J. R. Sanes (1984) Denervation supersensitivity in skeletal muscle: Analysis with a cloned cDNA probe. $J$ Cell Biol. 99: 332-335.

Miledi, R. (1960a) The acetylcholine sensitivity of frog muscle tibers after complete or partial denervation. J. Physiol. (Lond.) 151: 1-23.

Miledi, R. (1960b) Junctional and extrajunctional acetylcholine receptors in skeletal muscle fibers. J. Physiol. (Lond.) 151: 24-30.

Muller, R. D. J. Slamon, J. M. Tremblay, M. J. Cline, and I. M. Verma (1982) Differential expression of cellular oncogenes during pre- and postnatal development of the mouse. Nature 299: 640-643.

Neher, E., and B. Sakmann (1976) Noise analysis of drug induced voltage clamp currents in denervated frog muscle fibers. J. Physiol. (Lond.) 258. 705-736.

Noda, M., Y. Furutani, H. Takahashi, M. Toyosato, T. Tanabe, S. Shimizu, S. Kikyotani, T. Kayano, T. Hirose, S. Inayama, and S. Numa (1983) Cloning and sequence analysis of calf CDNA and human genomic DNA encoding alpha-subunit precursor of muscle acetylcholine receptor. Nature 305: 818-823.

Olson, E. N., L. Glaser, J. P. Merlie, and J. Lindstrom (1984) Expression of acetylcholine receptor $\alpha$-subunit mRNA during differentiation of the $\mathrm{BC}_{3} \mathrm{H}$ I muscle cell line. J. Biol. Chem. 259: 3330-3336.

Parada, L. F., C. J. Tabin, C. Shih, and R. A. Weinberg (1982) Human EJ bladder carcinoma oncogene is homologue of Harvey sarcoma virus ras gene. Nature 297: 474-478.

Parnes, J. R. R. R. Robinson, and J. G. Seidman (1983) Multiple mRNA species with distinct $3^{\prime}$ termini are transcribed from the $\beta_{2}$-microglobulin gene. Nature 302: 449-452.

Patrick, J., J. McMillan, H. Wolfson, and J. O'Brien (1977) Acetylcholine receptor metabolism in a non-fusing muscle cell line. J. Biol. Chem. 252: 2143-2153.

Puller, E., A. K. Nicolaison, E. S. Org, R. M. Evans, and M. G. Rosenfeld (1981) Thyrotropin-releasing hormone exerts rapid nuclear effects to increase production of the primary prolactin mRNA transcript. Proc. Natl. Acad. Sci. U. S. A. 78: 6662-6666.

Proudfoot, N. J., and G. G. Brownlee (1976) $3^{\prime}$ Non-coding region sequences in eukaryotic messenger RNA. Nature 263: 211-214.

Rigby, P. W. J., M. Diekmann, C. Rhodes, and P. Berg (1977) Labelling deoxyribonucleic acid to high specific activity in vitro by nick translation with DNA polymerase I. J. Mol. Biol. 113: 237-251.

Schubert, D., A. J. Harris, C. E. Devine, and S. Heinemann (1974) Characterization of a unique muscle cell line. J. Cell Biol. 61: 398-413.

Thomas, P. (1980) Hybridization of denatured RNA and small DNA fragments transferred to nitrocellulose. Proc. Natl. Acad. Sci. U. S. A. 77: 5201-5205.

Zehner, Z. E., and B. M. Paterson (1983) Vimentin gene expression during myogenesis: Two functional transcripts from a single copy gene. Nucleic Acids Res. 23: 8317-8332 